\title{
Cytogenetic bioassays as tools to distinguish between toxic and non-toxic varieties of Jatropha curcas (Euphorbiaceae)
}

\author{
Larissa Fonseca Andrade-Vieira ${ }^{1}$, Carolina Mastella Botelho², Carlos Alexandre Pinheiro ${ }^{3}$, \\ Patrícia Fontes Pinheiro ${ }^{3}$, Bruno Galvêas Laviola ${ }^{4} \&$ Milene Miranda Praça-Fontes ${ }^{2 *}$ \\ 1. Department of Biology, Universidade Federal de Lavras, 37200-000 Lavras - MG, Br; 1fandrade.vieira@gmail.com \\ 2. Departament of Biology, Center of Agronomical Sciences, Universidade Federal do Espírito Santo, 29500-000 Alegre \\ - ES, Br; c.mastellabotelho@gmail.com,milenemiranda@yahoo.com.br \\ 3. Departament of Chemistry and Physics, Center of Agronomical Sciences, Universidade Federal do Espírito Santo, \\ 29500-000 Alegre - ES, Br; xandre2010@yahoo.com.br, patriciafontespinheiro@yahoo.com.br \\ 4. Empresa Brasileira de Pesquisa Agropecuária (Embrapa Agroenergia), 70770-901 Brasília - DF, Br; \\ bruno.laviola@embrapa.br \\ * Correspondence
}

Received 13-XI-2017. C Corrected 08-III-2018. Accepted 06-IV-2018.

\begin{abstract}
The tropical and subtropical naturalized physic nut (Jatropha curcas L.), has been explored for biodiesel production in recent times. The oil is extracted from the seeds and, for the production to be feasible, utilization of the residual seed cake is crucial. Although the cake could be employed as a protein source in animal feed, it is rich in phorbol ester, which is toxic for animals. Therefore, breeding programs have been working to reduce or eliminate the phorbol ester content in physic nut. In this context, the present work aimed to evaluate the physic nut oil of toxic and non-toxic varieties (containing known or undetectable amounts of phorbol ester, respectively) with regards to phytotoxicity in a model experiment with Lactuca sativa L. For this, the percentage of germinated seeds was evaluated after $8,16,24,36$ and 48 hours of exposure to the treatments with toxic and non-toxic oil at concentrations of $22.5 \%, 45 \%$ and $67.5 \%$ of emulsion (physic nut oil energetically mixed with distilled water). Root growth was determined after 48 hours of exposure and the germination speed index was obtained. The different stages of mitotic division as well as possible chromosomal and nuclear alterations were also recorded. The mitotic index was calculated as the number of dividing cells, as a fraction of the total number of cells, and the frequency of chromosome and nuclear alterations, expressed as the percentage of number of alterations divided by the total number of cells. Both varieties exhibited phytotoxicity, inducing significant reductions in percentage of germinated seeds (reduction of $98 \%$ ), germination speed index (reduction of 24.44) and root growth (reduction of $8.54 \mathrm{~mm}$ ). In microscopic analysis, a mitodepressive effect was observed for both oils at the three concentrations used when compared to the negative control; however, it was possible to distinguish between the toxic and the non-toxic varieties based on the more expressive reduction of division promoted by the first, $2.19 \%$. Significant increments in the frequency of mitotic cells showing chromosome alterations as well, as the presence of condensed nuclei, were observed in the treated cells. However, these parameters were not significantly different from the control in the cells treated with both physic nut oils. In conclusion, the evaluation of root growth and cell division in the plant model L. sativa, can be proposed as an alternative to animal tests to distinguish the varieties with high and low phorbol ester concentration, thus contributing to the detection of toxicity in varieties used in breeding programs. Rev. Biol. Trop. 66(2): 495-502. Epub 2018 June 01.
\end{abstract}

Key words: root growth; seed germination; phytotoxicity; phorbol ester; mitodepressive effect.

Seeds of physic nut (Jatropha curcas L.) may present an oil content of approximately $50 \%$, representing a promising alternative for biodiesel production (Mendonça \& Laviola, 2009). However, because the oil extracted from the seeds contains toxic components (e.g. curcin and phorbol esters), exploitation of the cake -a protein-rich, solid-phase subproduct of the oil extraction- as animal feed or organic fertilizer becomes compromised (Andrew, 2009). 
The use of physic nut cake is of interest as feeding supplement for sheep, swine and other livestock, as well as for fertilization in agriculture, where it may generate important income and make these cultures more economically viable (Mendonça \& Laviola, 2009).

In this sense, studies have been performed attempting to decrease the seed concentration of phorbol ester, considered the main toxic compound of physic nut (Begg \& Gaskin, 2009), thus allowing the exploitation of the cake after oil extraction. In Brazil, Embrapa Agroenergy has been working on the breeding of physic nut varieties, aiming to reduce the phorbol ester content, and on processes that may help detoxify the subproduct. To test the efficiency of these two approaches, in vivo tests using animal models have been developed (Mendonça \& Laviola, 2009). However, because phorbol ester is toxic, the tests usually lead to the feed depression of the animals tested and if the feeding is forced can cause death, bringing up an ethical problem concerning the assertion of success of the research.

Therefore, alternative models to investigate the toxic potential of physic nut varieties with different contents of phorbol ester should be considered. Among the tests available to study the toxic potential of a given compound or residue, plant models stand out for their good sensitivity and low cost (Leme \& Marin-Morales, 2009), besides presenting good correlation with data from tests using animal models (Bianchi, Cabral-de-Mello, \& Marin-Morales, 2015) or even human cells (Palmieri, et al., 2016).

Hence, this work aimed to evaluate the effect of physic nut oil from varieties considered toxic (containing known amount of phorbol ester) or non-toxic (without detectable phorbol ester), on meristematic cells of Lactuca sativa L. (lettuce) - a plant model employed to detect macroscopic alterations, via seed germination and root growth, as well as microscopic changes, involving cytogenetic bioassays to evaluate the mitotic index and occurrence of chromosomal and nuclear alterations (Silveira, Lima, Reis, Palmieri, \& Andrade-Vieria,
2017). This way, efficiency of the plant model in distinguishing the studied varieties shall be verified, ultimately incorporating such tests in the toxicity analyses of different cultivars and in the validation of detoxication experiments, hence avoiding animal assays.

\section{MATERIAL AND METHODS}

Plant material: Physic nut seeds - toxic variety CNPAE $1010(4.21 \mathrm{mg} / \mathrm{g}$ of phorbol ester) and non-toxic variety CNPAE 1008 (undetected phorbol ester) - from the Active Germplasm Bank of Embrapa Agroenergy (Brazil) were kindly provided by the researcher Bruno Galvêas Laviola. The seeds were collected in November 2014 at the Rio Verde (GO, Brazil) and in July 2015 in Mexico. The experiment was conducted from May to July 2016.

Attainment of toxic and non-toxic oils and exposure of $L$. sativa seeds: Seeds of $L$. sativa L. $(2 \mathrm{n}=2 \mathrm{x}=18)$ var. Lechuga Grandes (Isla Seeds) were acquired at agricultural supply stores and used as model for the assays. To obtain physic nut oil, one kilogram of seeds from each variety (toxic and non-toxic) were cold-pressed using a manual press for extraction of cold fixed oils (hydraulic, 15 tons, model similar to Ph15 Skay) (São José do Rio Preto, São Paulo, Brazil).

The experiment was conceived in a completely randomized design (CRD) comprising five repetitions, each consisting of one Petri dish ( $9 \mathrm{~cm}$ diameter) containing 50 seeds. The seeds were disposed onto filter paper moistened with $10 \mathrm{~mL}$ of each treatment solution. The concentrations of $22.5 \%, 45 \%$ and $67.5 \%$ of emulsion (physic nut oil energetically mixed with distilled water) were evaluated, according to the $\mathrm{IC}_{50}$ determined by Andrade-Vieira, Botelho, Palmieri, Laviola, and Praça-Fontes, (2014). For each type of oil (toxic and nontoxic), emulsions were prepared at the three mentioned concentrations. Distilled water was used as negative control. In order to eliminate the effect of the oil's lipoid condition on germination and plantlet development, an emulsion 
of water and soybean oil (45\%) from Cargill (São Paulo, São Paulo, Brazil) was also tested. The germination conditions followed Aragão et al. (2015).

Macroscopic analyses: The percentage of germinated seeds was assessed after 8, 16, 24, 36 and 48 hours of treatment. Root growth was determined after 48 hours of exposure, using a digital caliper from Digimess Instrumentos de Precisão Ltda (Mooca, São Paulo, Brazil). In accordance with the calculations described by Aragão et al. (2015), the following parameters were obtained: percentage of germination after 48 hours (GR), germination speed index (GSI), and root growth (RG).

Microscopic analyses: For microscopic analysis, at least 20 roots of each treatment were collected after measurement (item 2.3). The roots were fixed and the slides were prepared and evaluated as described Aragão et al. (2015). Five slides were evaluated per treatment, with approximately 500-800 meristematic cells analyzed per slide, and the different stages of mitotic division as well as possible chromosomal and nuclear alterations were recorded. The mitotic index (MI) were calculated as the number of dividing cells as a fraction of the total number of cells, and the frequency of chromosome (CA) and nuclear alterations (NA), expressed as the percentage of number of alterations divided by the total number of cells (Aragão et al., 2015).

The evaluated parameters (GR, GSI, RG, MI, CA and NA) were subjected to analysis of variance $(\alpha=0.05)$, and the obtained mean values were compared by the test of KruskalWallis or Dunnett at $5 \%$ significance level, as most suitable for each parameter. The statistical analyses were performed with the program $\mathrm{R}$ (R Development Core Team, 2011).

\section{RESULTS}

Compared to the soybean oil, significant difference was observed in the percentage of germinated seeds (GR) and GSI in relation to water, demonstrating that the reductions in GR and $R G$ in the treatments with physic nut oil are due to its chemical components (Table 1). Further, the RG in soybean oil was statistically similar to that in water.

Figure 1 gives an overview of the effects of the studied physic nut varieties (toxic and nontoxic) on the macroscopic parameters (GR, GSI and RG). For both oils, significant reduction in GR was obtained at the highest concentrations (45.0\% and $67.5 \%$ ). Regarding GSI and RG, all tested concentrations differed from water,

TABLE 1

Effects of physic nut oil over the germination and plants growth on the plant model Lactuca sativa

\begin{tabular}{lcccccc}
\multicolumn{1}{c}{ Treatments } & \multicolumn{2}{c}{ GR $(\%)$} & GSI & \multicolumn{2}{c}{ RG $(\mathrm{mm})$} \\
Negative control & Mean & SD & Mean & SD & Mean & SD \\
JC11 & 99.2 & 3.30 & 24.57 & 0.80 & 8.60 & 1.86 \\
JC12 & 99.6 & 2.10 & $16.55^{*}$ & 1.10 & $6.73^{*}$ & 1.10 \\
JC13 & $52.8^{*}$ & 1.30 & $6.75^{*}$ & 1.70 & $2.57^{*}$ & 1.30 \\
JC21 & $10.8^{*}$ & 0.82 & $1.13^{*}$ & 0.38 & $0.31^{*}$ & 0.03 \\
JC22 & 98.8 & 3.10 & $15.55^{*}$ & 1.80 & $5.39^{*}$ & 1.52 \\
JC23 & $36^{*}$ & 1.45 & $4.24^{*}$ & 1.30 & $1.53^{*}$ & 0.31 \\
Soybean oil & $1.2 *$ & 0.32 & $0.13^{*}$ & 0.02 & $0.06^{*}$ & 0.02 \\
\hline
\end{tabular}

Abreviations means: GR - Germination Ratios; GSI - Germination Speed Index; RG - Root Growth; SD - Standard Deviation. The treatments JC11, JC12 and JC13 refeer to the non-toxic oil at the concentrations: JC11 = $22.5 \%$ JC12=45 $\%$ and $\mathrm{JC} 13=67.5 \%$. The treatments JC21, JC22 and JC23 refeer to the toxic oil and the following concentrations: JC21 $=22.5 \% ; \mathrm{JC} 22=45 \%$ and $\mathrm{JC} 23=67.5 \%$.

Means followed by * are statistically different from the negative control (distilled water) by Dunnet's Test $\mathrm{p}<0.05$. 


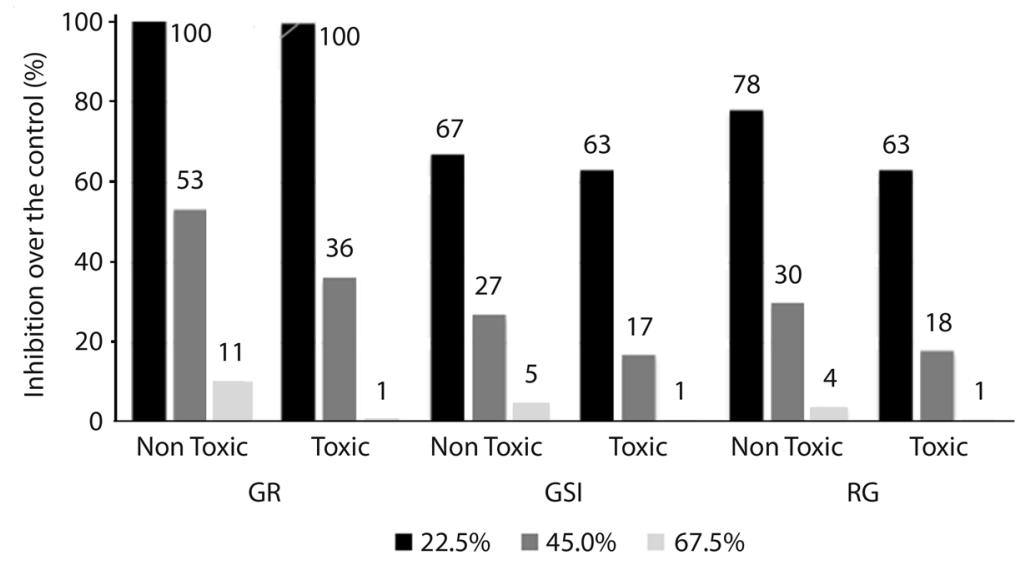

Fig. 1. Inhibitory effects of physic nut toxic and non-toxic oil at the concentrations of $22.5 \%, 45 \%$ and $67.5 \%$ of emulsion over the the germination and seedlings growth on the plant model Lactuca sativa. GR - Germination Ratios; GSI Germination Speed Index; RG - Root Growth.

whether toxic or non-toxic variety (Table 1). For the first tested concentration of $22.5 \%$ of each oil (JC11 being non-toxic and JC21 being toxic), both varieties presented similar effects on the three evaluated parameters (Fig. 1, Table $1)$. In the second tested concentration (45\%), the toxic oil caused a reduction $32 \%$ greater in GR than the non-toxic oil. For this same parameter, at the highest concentration $(67.5 \%)$ the reduction increased to $90 \%$ for the toxic in relation to the non-toxic oil (Table 1). This pattern of 30-40 \% reduction for toxic in relation to non-toxic oil at the second concentration, and of $80-90 \%$ at the highest concentration, was observed in the three assessed macroscopic parameters (Fig. 1, Table 1).

Here, observing the MI of meristematic cells of $L$. sativa (Table 2), a significant reduction in dividing cells was verified for the treatments with toxic and non-toxic physic nut oil in relation to water or soybean oil. The non-toxic oil inhibited the MI of the exposed cells from $17 \%$ to $26 \%$ in comparison to water, whereas the toxic oil caused a reduction from $52 \%$ to $70 \%$ (Table 2).

TABLE 2

Effects of physic nut oil over the cell cycle of root tips cells from the plant model Lactuca sativa

\begin{tabular}{lcccccc}
\multicolumn{1}{c}{ Trataments } & \multicolumn{2}{c}{ MI (\%) } & \multicolumn{3}{c}{ NA (mm) } \\
Negative Control & Mean & SD & Mean & SD & Mean & SD \\
JC11 & $7.11 \mathrm{a}$ & 1.23 & $0.00 \mathrm{a}$ & 0.00 & $2.55 \mathrm{a}$ & 0.43 \\
$\mathrm{JC12}$ & $5.94 \mathrm{c}$ & 1.96 & $0.05 \mathrm{a}$ & 0.01 & $1.37 \mathrm{a}$ & 0.82 \\
$\mathrm{JC13}$ & $5.90 \mathrm{c}$ & 1.74 & $0.09 \mathrm{a}$ & 0.04 & $1.53 \mathrm{a}$ & 0.95 \\
$\mathrm{JC21}$ & $5.29 \mathrm{c}$ & 1.47 & $0.07 \mathrm{a}$ & 0.06 & $4.91 \mathrm{a}$ & 1.59 \\
$\mathrm{JC22}$ & $3.34 \mathrm{~d}$ & 1.67 & $0.12 \mathrm{a}$ & 0.07 & $2.23 \mathrm{a}$ & 0.79 \\
JC23 & $3.39 \mathrm{~d}$ & 1.62 & $0.08 \mathrm{a}$ & 0.05 & $5.91 \mathrm{a}$ & 1.13 \\
Soybean Oil & $2.19 \mathrm{e}$ & 0.74 & $0.13 \mathrm{a}$ & 0.05 & $2.26 \mathrm{a}$ & 1.73 \\
\hline
\end{tabular}

Abreviations means: MI - Mitotic Index; CA - Chromosome Alteration; NA - Nuclear Alteration; SD - Standard Deviation. The treatments JC11, JC12 and JC13 refeer to the non-toxic oil at the concentrations: JC11 $=22.5 \%$;C12=45\% and $\mathrm{JC} 13=67.5 \%$. The treatments JC21, JC22 and JC23 refeer to the toxic oil and the following concentrations: JC21 $=22.5$ $\% ; \mathrm{JC} 22=45 \%$ and $\mathrm{JC} 23=67.5 \%$.

Means followed by different letter at the column are statistically different from each other by Kruskal Wallis Test $\mathrm{p}<0.05$. 

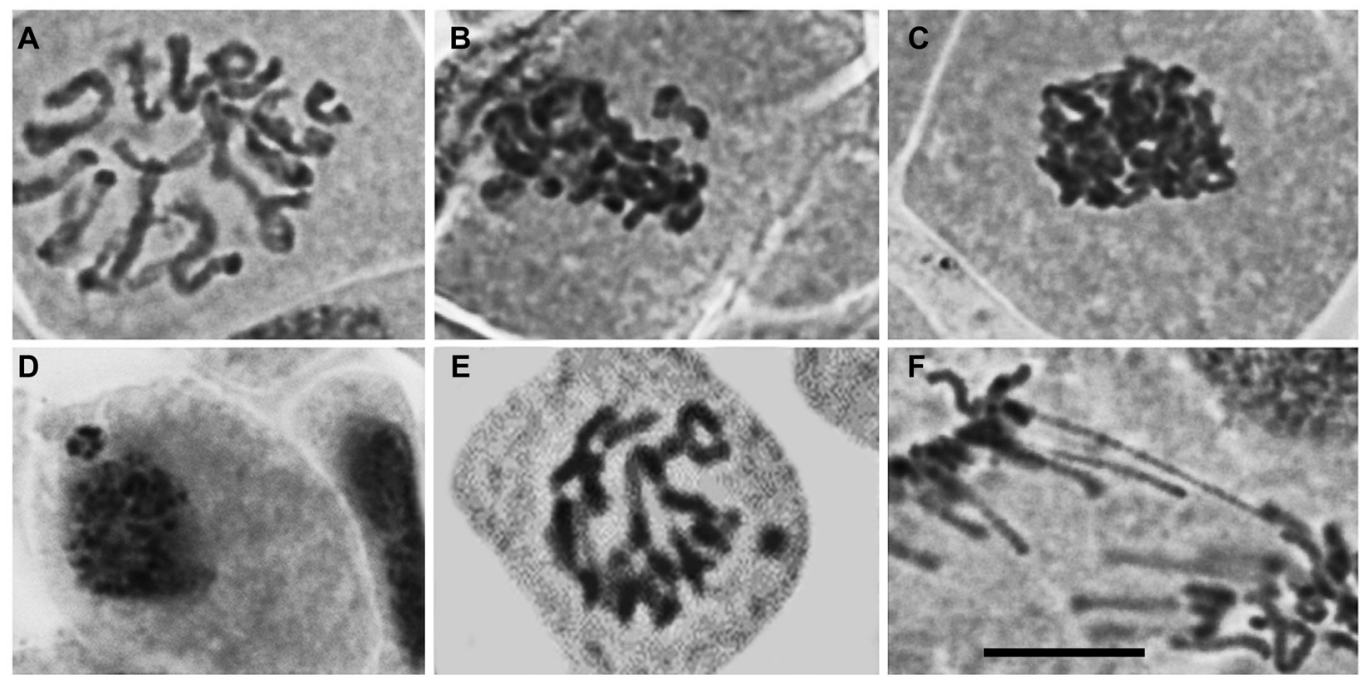

Fig. 2. Exemple of the main cell cycle alterations observed on the root tip cells of Lactuca sativa exposed to physic nut oil (toxic and non-toxic). (A) C-metaphasis, note that chromosomes are not aligned at the equatorial cell plate; (B) non-oriented chromosomes in relation the metaphasic plate; (C) sticky chromosomes in metaphasis; (D) micronuclei in interphase; (E) micronuclei in prophasis; (F) anaphasis bridge. The images were captured on the 40X objective under the Olympus BX60 microscope. Bar $=10 \mu \mathrm{m}$.

The possible chromosomal alterations due to toxicity of phorbol ester were also assessed (Table 2). All treatments induced cell cycle alterations (CCA). The frequency of CCA in water was $0 \%$, whereas in the treatments it varied from $0.05 \%$ (lowest concentration of the non-toxic oil) to $0.13 \%$ (highest concentration of toxic oil), without statistical differences to the control (water) (Table 2). Among the verified alterations, the most frequent were chromosomes mis-orientation in the mitotic spindle, adhered chromosomes, bridges, and micronuclei (Fig. 2).

\section{DISCUSSION}

Lettuce is an excellent model for macroscopic analyses, as it allows the evaluation of adverse events of a toxic compound on germination and root growth from the early initial phases of seed development in according to Valerio, García and Peinado (2007). The statistical differences regarding the dynamics of germination and growth of roots exposed to physic nut oil was obtained after 48 hours of exposure, showing that, when present, the toxicity response is rapid. Moreover, the applied test requires little time, is simple and of low cost, which corroborates the perception of other authors on the use of macroscopic tests to investigate the toxic effects of any simple substance or chemical compound (Palmieri, Luber, Andrade, \& Davide, 2014; Silveira, et al., 2017). Pinheiro et al., (2015) investigated the essential oil action of leaves of Plectranthus amboinicus, Carvacrol, and Thymol on lettuce, observing the toxic action of these compounds on seed development. Lettuce was also used to investigate the cytogenotoxic effect of the ethanolic extract of leaves of Annona crassiflora, with a significant reduction in seed germination (Ribeiro et al., 2013).

In addition, it was observed that the presence of compounds like phorbol ester in the physic nut oil, even in varieties considered non-toxic by chemical analysis due to presenting low content of the ester, is sufficient to significantly inhibit both germination and root growth of developing plantlets. Andrade-Vieira et al. (2014) attributed the inhibitory effect of physic nut on root growth to phorbol ester, via mechanisms related to activation of proteins 
that hamper the progression of the cell cycle, demonstrated by inhibition of MI. These data strengthen the discussion of Andrade-Vieira et al. (2014) that the presence of phorbol ester, a diterpene analogous to diacylglycerol (King, et al., 2009), hampers the transition of the cell cycle, maintaining the activation of the protein kinase $\mathrm{C}$ for a longer period.

In accordance to Andrade-Vieira, et al., (2014) the toxicity of $J$. curcas seeds has been examined with various bioassays by using animals such as cattle, goats and fish as test systems. The goals of such bioassays lie in the interests of using the plant seed for biodiesel production and in animal nutrition, and hence, in making its use more economically viable. However, if the seed is toxic it can lead to the death of the animals. Therefore, tests with lettuce may be an alternative for such purposes.

With the results obtained in the present study, it is possible to note that the tests carried out with L. sativa reveal the toxicity potential of the J. curcas seeds, and confirmed that the phytotoxic and mitodepressive effect of phorbol ester is dependent on its concentration and availability to the cells. In the toxic varieties, where it is present in amounts considered high (4.21 mg of phorbol ester per $1 \mathrm{~g}$ of seed) (Makkar, Becker, Sporer, \& Wink, 1997), this mitodepressive effect is more pronounced with increasing concentration of the oil and, consequently, of phorbol ester. This becomes evident when comparing the MI of toxic and non-toxic oil (i.e. without phorbol ester): the toxic oil inhibits cell division by $50 \%$ more than the non-toxic type. In addition, according to Fiskejö (1993), only mitodepressive effects above $50 \%$ indicate toxicity of a compound. This way, only the oil considered toxic was effectively cytotoxic.

The alterations classified as aneugenic, related to malfunctioning of the mitotic spindle, including non-oriented chromosomes and c-metaphases (Leme \& Marin-Morales, 2009), were the most frequent in previous studies carried out by Andrade-Vieira et al. (2014), who showed for the first time, the application of a plant model test to investigate the effect of physic nut oil. Corroborating the data obtained by those authors, here the presence of adherent chromosomes was also recurrent, reinforcing the cytotoxicity of physic nut oil and its effects on cell proteins (Andrade-Viera, et al., 2014). The presence of condensed nuclei, which may be related to cell death process (Andrade-Vieira, Gedraite, Campos, \& Davide, 2011), was also detected in this work, though the treatments did not differ statistically from the control.

In conclusion, the toxic potential of the physic nut oil was demonstrated by the reduction in macroscopic parameters like GR and RG and microscopic criteria such as MI; thus, the oil can be classified as phytotoxic and cytotoxic. Moreover, the toxic oil, with known higher content of phorbol ester, presented more pronounced phyto- and cytotoxic effects than the non-toxic oil, which has undetected phorbol ester content. In this way, the phytotoxic and cytogenetic bioassays distinguished toxic and non-toxic varieties from $J$. curcas. This tool can help identify non-toxic varieties in order to verify the efficiency of detoxification. The assessed parameters, especially RG and MI, were efficient in the investigation of physic nut oil toxicity, allowing the distinction between toxic and non-toxic varieties at any analyzed concentration. Hence, the evaluation of root growth and cell division in the plant model $L$. sativa can be proposed as an alternative to animal tests to distinguish the varieties with high and low phorbol ester concentration.

\section{ACKNOWLEDGMENTS}

The authors thanks to the Federal University of Espírito Santo for the structure and materials provided for to this work, and to the Conselho Nacional de Desenvolvimento Científico e Tecnológico (CNPq) and Fundação de Amparo à Pesquisa do Espírito Santo (FAPES) for financial support.

\section{RESUMEN}

Jatropha curcas L., naturalizado tropical y subtropical, ha sido explorado para la producción de biodiesel. El 
aceite se extrae de las semillas y, para que la producción sea factible, la utilización de la torta de semillas residual es crucial. Aunque la torta se puede emplear como una fuente de proteína en la alimentación animal, es rica en éster de forbol, que es tóxico para los animales. Por lo tanto, los programas de mejoramiento han procurado reducir o eliminar el contenido de éster de forbol de J. curcas. En este contexto, el presente trabajo tuvo como objetivo evaluar el aceite de $J$. curcas de las variedades tóxicas y no tóxicas (con cantidades conocidas o indetectables de éster de forbol, respectivamente) con respecto a la fitotoxicidad en el modelo Lactuca sativa L. El porcentaje de semillas germinadas se evaluó después de 8, 16, 24, 36 y 48 horas de tratamiento. El crecimiento de la raíz se determinó después de 48 horas de exposición y se obtuvo el índice de velocidad de germinación. Se registraron las diferentes etapas de la división mitótica así como posibles alteraciones cromosómicas y nucleares. El índice mitótico se calculó como el número de células en división como una fracción del número total de células y la frecuencia de las alteraciones cromosómicas y nucleares, expresada como el porcentaje del número de alteraciones dividido entre el número total de células. Ambas variedades exhibieron fitotoxicidad, induciendo reducciones significativas en el porcentaje de semillas germinadas (Reducción del $98 \%$ ), índice de velocidad de germinación (Reducción de 24.44) y crecimiento de raíces (Reducción de $8.54 \mathrm{~mm}$ ). En el análisis microscópico, se observó un efecto mitodepresivo para ambos aceites. Sin embargo, fue posible distinguir entre las variedades tóxicas y las no tóxicas basándose en la reducción más expresiva de la división promovida por la primera, $2.19 \%$. Se observaron incrementos significativos en la frecuencia de células mitóticas que mostraban alteraciones cromosómicas, así como la presencia de núcleos condensados en las células tratadas. Sin embargo, estos parámetros no fueron significativamente diferentes del control en las células tratadas con ambos aceites de $J$. curcas. En conclusión, la evaluación del crecimiento de las raíces y la división celular en el modelo $L$. sativa se puede proponer como una alternativa a las pruebas en animales para distinguir las variedades con concentraciones altas y bajas de éster de forbol, contribuyendo así a la detección de toxicidad en variedades utilizadas en programas de mejoramiento genético.

Palabras clave: crecimiento de raíces; germinación de la semilla; fitotoxicidad; éster de forbol; efecto mitodepresivo.

\section{REFERENCES}

Andrade-Vieira, L. F., Botelho, C. M., Palmieri, M. J., Laviola, B. G., \& Praça-Fontes, M. M. (2014). Effects of Jatropha curcas oil in Lactuca sativa root tip bioassays. Anais da Academia Brasileira de Ciências (Printed), 86, 373-382.
Andrade-Vieira, L. F., Gedraite, L. S., Campos, J. M. S., \& Davide, L. C. (2011). Spent Pot Liner (SPL) induced DNA damage and nuclear alterations in root tip cells of Allium cepa as a consequence of programmed cell death. Ecotoxicology and Environmental Safety, 74, 822-828.

Aragao, F. B., Andrade-Vieira, L. F., Ferreira, A., Costa, A. V., Queiroz, V. T., \& Pinheiro, P. F. (2015). Phytotoxic and cytotoxic effects of Eucalyptus essential oil on Lactuca sativa L. Allelopathy Journal, 35, 259-272.

Begg, J., \& Gaskin, T. (2015). Jatropha Curcas. (PIM570). In CHEMICAL Safety Information from Intergovernmental Organizations. Available at <http:// www.inchem.org/documents/pims/plant/jcurc.htm $>$. Accessed on 8 June 2015.

Bianchi, J., Cabral-de-Mello, D. C., \& Marin-Morales, M. A. (2015). Toxicogenetic effects of low concentrations of the pesticides imidacloprid and sulfentrazone individually and in combination in in vitro tests with HepG2 cells and Salmonella typhimurium. Ecotoxicology and Environmental Safety, 120, 174-183.

Fiskesjö, G. (1993). The Allium test - a potential standard for the assessment of environmental toxicity. American Society for Testing Materials, 2, 331-345.

King, A. J., He, W., Cuevas, J. A., Freudenberger, M., Ramiaramanana, D., \& Graham, I. A. (2009). Potential of Jatropha curcas as source of renewable oil and animal feed. Journal of Experimental Botany, 60, 2897-2905.

Leme, D. M., \& Marin-Morales, M. A. (2009). Allium cepa test in environmental monitoring: A review on its application. Mutation Research, 682, 71-81.

Makkar, H. P. S., Becker, K., Sporer, F., \& Wink, M. (1997). Studies on nutritive potential and toxic constituents of different provenances of Jatropha curcas L. Journal of Agricultural and Food Chemistry, 45, 3152-3157.

Mendonça, S., \& Laviola, B. G. (2009). Uso Potencial e Toxidez da Torta de Pinhão-manso. (Comunicado técnico). Embrapa Agroenergia: Brasilia.

Palmieri, M. J., Andrade-Vieira, L. F., Trento, M. V. C., Eleutério, M. W. F., Luber, J., Davide, L. C., \& Marcussi, S. (2016). Cytogenotoxic effects of Spent Pot Liner (SPL) and its main components on human leukocytes and meristematic cells of Allium cepa. Water, Air, Soil Pollution, 227, 1-10.

Palmieri, M. J., Luber, J., Andrade, L. F., \& Davide, L. C. (2014). Cytotoxic and phytotoxic effects on the main chemical components of spent pot-liner: A comparative approach. Mutation Research, 763, 30-55.

Pinheiro, P. F., Costa, A. V., Alves, T. A., Galter, I. N., Pinheiro, C. A., Pereira, A. F., Carlos Oliveira, C. 
M. R., \& Fontes, M. M. P. (2015). Phytotoxicity and Cytotoxicity of Essential Oil from Leaves of Plectranthus amboinicus, Carvacrol, and Thymol in Plant Bioassays. Journal of Agricultural and Food Chemistry, 63, 8981-8990.

R Development Core Team (2011). R: A Language and Environment for Statistical Computing. Vienna, Austria: the R Foundation for Statistical Computing. ISBN: 3-900051-07-0. Available online at http:// www.R-project.org/

Ribeiro, L. R., Santos, M. F., Silva, Q. M., Palmieri, M. J., Larissa, F., Andrade-Vieira, L. F., \& Davide, L. C.
(2013). Cytogenotoxic effects of ethanolic extracts of Annona crassiflora (Annonaceae). Biologia, 68, 433-438.

Silveira, G. L., Lima, M. G. F., Reis, G. B., Palmieri, M. J., \& Andrade-Vieria, L. F. (2017). Toxic effects of environmental pollutants: Comparative investigation using Allium cepa L. and Lactuca sativa L. Chemosphere (Oxford), 178, 359-367.

Valerio, M. E., García, J. F., \& Peinado, F. M. (2007). Determination of phytotoxicity of soluble elements in soils, based on a bioassay with lettuce (Lactuca sativa L.). Science of the Total Environment, 378, 63-66. 